\title{
STUDENTS' ATTITUDES TOWARDS LANGUAGES AND MAINTENANCE OF HERITAGE LANGUAGES: A CASE STUDY OF PAPUAN SENIOR HIGH SCHOOL STUDENTS
}

\author{
Kasih Elisabet Roostini and Christine Manara* \\ Atma Jaya Catholic University of Indonesia \\ Received on 15 March 2021 / Approved on 6 October 2021
}

\begin{abstract}
Language shift may lead to language investment, and it may also affect language heritage maintenance. This case study aims to explore maintenance of language heritage among a group of Papuan students who are living in a school dormitory, away from their families. These 29 senior high school students are originally from different ethnic groups from several districts in Papua. A questionnaire and a semi-structured interview videorecorded for data collection were employed to find out the students' attitudes towards languages and maintenance of heritage languages. The questionnaire was designed and developed by adapting the semistructured interview questions designed by Berman et al. (2011). The data were analysed based on the aspects organised in the questionnaire and the results were compared with the findings of Berman et al.'s (2011), Ehala and Niglas's (2006), and Nguyen's (2018) studies. The result shows that there has been a language shift among these adolescents. Living among a community that is totally different from theirs has driven them to adapt and accept the language used in the community. Technology exposure at school has also affected their perspectives towards their future, which motivates them to invest in other languages that they think are important for their future career. Their positive attitudes towards other languages do not discourage them from maintaining their heritage language, as they perceive the use of heritage language as a way to stay connected with their own culture.
\end{abstract}

Keywords: language shift; language maintenance; heritage language; language investment; identity

\section{ABSTRAK}

Pergeseran bahasa dapat mengarah pada investasi bahasa, dan hal tersebut dapat mempengaruhi pemeliharaan bahasa warisan. Studi kasus ini bertujuan mengeksplorasi pemeliharaaan Bahasa warisan di antara sekelompok siswa yang berasal dari Papua yang tinggal di sebuah asrama sekolah, jauh dari keluarga. Ke-29 siswa sekolah menengah atas ini berasal dari suku yang berbeda dari beberapa daerah di Papua. Data untuk studi ini, yang didapatkan melalui kuesioner dan wawancara semi-terstruktur yang direkam dalam bentuk video, digunakan untuk mengungkapkan sikap siswa terhadap bahasa dan terhadap pemeliharaan bahasa warisan. Kuesioner dirancang dan dikembangkan berdasarkan adaptasi dari pertanyaan wawancara semiterstruktur yang dirancang oleh Berman dkk. (2011). Data yang diperoleh kemudian dianalisa berdasarkan aspek-aspek yang disusun dalam kuesioner dan hasilnya dibadingkan dengan temuan dalam studi yang dilakukan oleh Berman dkk. (2011), Ehala dan Niglas (2006), dan Nguyen (2018). Hasilnya menunjukkan bahwa memang terjadi pergeseran bahasa di antara siswa remaja ini. Tinggal di komunitas yang sangat berbeda dari komunitasnya sendiri telah mendorong siswa-siswa ini untuk beradaptasi dan menerima bahasa yang digunakan di komunitas tersebut. Paparan teknologi di sekolah juga telah mempengaruhi pandangan mereka terhadap masa depan mereka, yang memotivasi mereka untuk berinvestasi pada bahasa lain yang mereka pikir penting bagi karir masa depan mereka. Sikap positif mereka terhadap bahasa lain tidak membuat mereka kecil hati untuk tetap menggunakan Bahasa warisan mereka, karena mereka berpandangan bahwa menggunakan bahasa warisan mereka adalah satu cara untuk tetap berhubungan dengan budaya mereka sendiri.

Kata Kunci: pergeseran bahasa, pemeliharaan bahasa, bahasa warisan, investasi Bahasa, identitas

\footnotetext{
*Author(s) Correspondence:

E-mail: kasih.er@atmajaya.ac.id; manara.christine@gmail.com
} 


\section{INTRODUCTION}

Rapid changes all over the world have created a new map of language use that keeps changing as well. People moving from one region to another means movement of language users. People moving to another region might still maintain their "home" language or heritage language (HL). However, there is also a chance that people stop using their heritage language as they need to adapt to their new environment for survival. Such dynamic phenomena have always been an interesting issue to study. Therefore, studies on HL can be such an evergreen topic. Indeed, there have been a great deal of studies on HL (Alsahafi, 2019; Farr et al., 2018; Budiyana, 2017; Huia, 2015; Polinsky, 2015; Russell \& Kuriscak, 2015; Berman et al., 2011; Ehala \& Niglas, 2006; and Cho, 2000). One most recent study by Armon-Lotem (2021) offers an interesting new insight on HL in relation with bilingualism, specifically with the age onset of bilingualism. Other studies relate HL to family language identity (Little, 2020), to religion (Ding and Goh, 2019), to language use with children within language shift between the host and HL used by migrant mothers (Farr et al., 2018), to bilingual identity (Nguyen, 2018), and to literacy, media consumption, and social media (Velázquez, 2017).

While Russell \& Kuriscak (2015) conducted a study on pre-service teachers' attitudes towards HL learning as a pedagogical practice, Alsahafi (2019) investigated maintenance and development of Arabic as HL among children attending an Arabic weekend school from teachers, parents, and students' perspectives. Similar to Alsahafi's (2019) study, which shows teachers and parents' support toward maintenance of HL through a weekend school, Russell and Kuriscak's (2015) study also shows teachers' support towards the practice of HL learning. Such parents' support reflects their desire to maintain their HL (Little, 2020; Farr et al., 2018; and Budiyana, 2017).
In the aforementioned studies, the children or respondents live with their families. This study focuses on a group of adolescents who live in a school dormitory, separated from their families to complete their study. These adolescents were brought away from their hometowns in Papua for twelveyear free education in a far-away island near the capital city of Indonesia. Leaving their families behind, these students persevere with dreams for a better future in a new community. In this new home, they have to deal with new environments, new communities, and new languages. Back in their hometowns they were used to dealing with different ethnic groups and diverse HLs, which made them choose to use the lingua franca in Indonesia: Indonesian. Moving to this new environment may have affected their cultural identities and their choice for investment for their future. Their present situation may serve an example of a language shift as in this new home these students have to decide which language to use in their social interaction. There is a question whether they will maintain their HL they were exposed to in their childhood.

This study, therefore, intends to examine their attitudes toward languages and the maintenance of their HL. In particular, it will seek answers to the following questions:

1. What are the students' attitudes towards languages and their heritage language?

2. What other languages are they investing in?

3. Why are they investing in that (those) language(s)?

4. What are the values of each language to them?

To answer those questions, the folllowing theoretical review provides definitions of HL and discusses language investment and identity.

\section{LITERATURE REVIEW}

\section{Heritage Speakers}

Fishman (2001 as cited in Gass \& Glew in Altarriba \& Heredia, 2008, p. 269)

\footnotetext{
*Author(s) Correspondence:

E-mail: kasih.er@atmajaya.ac.id; manara.christine@gmail.com
} 
defines HL speakers in terms of the speakers' personal connection with the language exposed to them, in line with Polinsky (2015, p.7), who describes heritage speakers as those who have "a cultural or familial connection" to their HL, even though their language proficiency in the dominant language may exceed that of their HL. Such a feeling of familial connection created through HL can be captured in Little's (2020), Alsahafi's (2019), Farr et al.'s (2018), Budiyana's (2017), Huia's (2015), and He's (2010 in Norton \& Toohey, 2011) studies. In He's (2010, p.66, as cited in Norton \& Toohey, 2011, p. 431) study, one of the Chinese participants could not read or write in Chinese but would directly think of his/her parents and home once he/she thinks of 'Chinese.'

However, heritage speakers may also be bilingual to some certain degree. These HL speakers can be referred as individuals who were exposed to HL at home but at the same time also exposed to the dominant language of the community, and therefore "possess some degree of bilingualism in the heritage language and the dominant language (Polinsky, 2015, p. 8 ). The degree of bilingualism depends on the length and manner of home exposure, which inevitably affect a child's bilingualism development (Polinsky, 2015, p. 10).

Such bilingualism development can be seen in Cho's (2015) and Berman et al.'s (2011) studies. Cho investigated second generation adolescent Korean Americans, focusing on the factors that facilitate or inhibit the HL development in relations with their identity, ethnic identity, and their attitudes toward HL development and HL speakers. She distributed her questionnaire to 260 secondgeneration Korean American high school students and interviewed seven of them. Her findings revealed a shift from Korean to English, the majority language, among these adolescents. The majority of her respondents admitted to using English mostly with their siblings and close friends, and some used both Korean and English with their parents. In spite of this strong shift toward the society language, about $75 \%$ of the students still found being able to speak Korean important. The reasons for them to maintain their HL were to be closer to their families, to be able to speak to other Korean speakers, to understand their culture, and to improve their future career opportunities. The factors identified to facilitate the HL development were communicating in Korean when visiting or living in Korea, joining conversations with native Korean speakers, attending Korean classes, and doing informal language learning activities such as watching Korean television, listening to Korean music, and reading books written in Korean (Cho, p. 36).

\section{Language Investment and Identity}

Berman et al. (2011) studied four young Polish adolescents' attitudes to Icelandic, Polish and English languages and cultures. These 12-to-13 year old adolescents were immigrants in Iceland. Their study aims to see if they were motivated to learn Icelandic - as it was the language of the society, school, and every-day lives of these adolescents - and at the same time maintain their heritage language-Polish-and their culture; besides, they also intended to find out if their language learning was impeded by the obligation to learn English at the same time. Through a 30-minute semi-structured interview with each of the participants, the researcher tried to see how the participants lived on the daily basis: maintaining their heritage language and culture and integrating to Icelandic society.

The result showed that "these adolescents have achieved a level of plurilingual competence which enables them to use different languages for a variety of purposes" (Berman et al., 2011, p. 9). At home, the dominant language they used with their parents was Polish, but they also helped their parents practice in or translate from Polish to Icelandic and vice versa; they showed no difficulty to code-switch between the two languages. They also used Polish when communicating with friends in social media or during holiday visits. Meanwhile, outside home and at school, they used Icelandic - the language used among people from other countries who lived in Iceland, not English-

\footnotetext{
*Author(s) Correspondence:

E-mail: kasih.er@atmajaya.ac.id; manara.christine@gmail.com
} 
with their peers. Referring to Polinsky's (2015, p. 8) definition of heritage speakers, these adolescents could be defined as heritage speakers as the language they used at home was Polish but the language that predominated their daily lives outside home was Icelandic. English was used for leisure-such as listening to songs, watching movies, and possibly traveling in the future-and preparation for their future.

In relation with the cultures of Polish and Icelandic, even though they experienced differences, they showed positive attitudes and seemed to be able to deal with the differences. At the beginning they had trouble learning Icelandic, but they were able to cope with the new language and culture with optimism and willingness to integrate to the society, as they perceived Iceland as their future.

In both studies above, the adolescents' attitudes seem to project what is called language investment, as they have shown how the environmental and linguistic changes have brought them to new identities. According to Darvin and Norton (2016, p. 20), Norton's "construct of investment recognizes that language learners have complex, multiple identities, changing across time and space, reproduced in social interaction." To project the complexities of the unceasing language shift, linguistic repertoires, and the negotiation of power, Darvin and Norton (2015 as cited in Darvin \& Norton, 2016, p. 24) offer their model of investment that "locates investment at the intersection of identity, capital, and ideology", which has put the advancement of technology of the $21^{\text {st }}$ century. Learners experiences ideologies collision when they move across spaces - by migration-forcing them to seek new positions. Traveling across time and space also push them to see different values economically culturally, and socially. All these changes have driven them away from their "prior knowledge, home literacies, and mother tongue as symbolic capital" (Darvin \& Norton, 2016, p. 24-25) to their investment in their new world.

The study by Ehala and Niglas (2006) shows an example of language shift driven by the change of identity that drive adolescents to invest in English. Ehala and Niglas (2006) conducted a large-scale study with 1,964 secondary school students to find out their attitudes towards Estonian - the mother tongue of most of the respondents - in a bicultural context with English. The result shows that most students considered Estonian as a "token of identity and not so much as a commodity in the sense of linguistic economy" (p. 209).

Compared to the studies above, this study is a small-scale and conducted through close-ended questions in the questionnaire and supported by an interview. The result of this study may not be as rich and in-depth as those using open-ended questions and one-to-one interviews.

\section{RESEARCH METHODOLOGY}

This small-scale research was conducted at a private school located in Bogor, West Java, Indonesia. It is sponsored by a nongovernmental foundation, who provides free education to the Papuan children. The school runs elementary, junior, and senior high school. The school is located near the capital city of Indonesia, on a different island very far away from Papua in the far east of the capital city. The distance between the capital city and Papua is approximately 4-8 hours by flight, excluding the land travel. This school was chosen for this research as it offers an opportunity to meet a group of students of diverse ethnic groups who live separately from their families.

The participants were senior high school: seventeen $10^{\text {th }}$ graders, four $11^{\text {th }}$ graders, and eight $12^{\text {th }}$ graders -17 male and 12 female - some are originally from remote areas, such as Asmat, Tambrauw, Tolikara, and Mamberamo Raya; and few are from a big city: Sorong, in West Papua. Originally, there were a total of 30 students from all the five classes, but one student was absent. They all stayed in the school dormitory located outside the school area. These students were allowed to visit their family in Papua during the school holidays. The majority of the students started to join this school from elementary, whereas

\footnotetext{
*Author(s) Correspondence:

E-mail: kasih.er@atmajaya.ac.id; manara.christine@gmail.com
} 
some others from junior high, and the others from senior high.

This research employed a questionnaire and a forum group discussion (FGD) that was video-recorded for data collection. The language used in both the questionnaire and FGD is Indonesian, the language of the society and language instruction at school. The questionnaire was designed and developed by adapting the semistructured interview questions designed by Berman et al. (2011), which originally consisted of open and closed questions about attitudes towards learning Icelandic language and culture, and participation in Icelandic society, maintaining their Polish language and culture, and learning English.

The questionnaire in the present study, adapted from and developed based on Berman et al.'s (2011) questionnaire, comprises four parts: questions for their biodata, questions about the language and its functions, questions about the speech domain, and questions about their attitudes toward each language. Most questions in the present questionnaire adapted Berman et al.'s (2011) questions as they focus on similar aspects concerning the students' attitudes towards languages and heritage languages. However, this study provided detailed options to the students while allowing them to express their own opinions in the questionnaire. The first part of the questionnaire is to elicit background information about the participant. It is in the form of fill-in the blanks, whereas the second, third and fourth parts are in the form of tables.

The second part of the instrument is to elicit the students' languages and their functions. The second provides 12 items with language choices to select. The third part is to find out the speech domain, the result of which may show a variety of contexts in which each language is used. It covers eight segments (A $\mathrm{H}$ ), each of which contain 5 to 6 items with a Likert scale for 4 choices: Always, Often, Seldom, and Never. The fourth part is to explore the students' attitudes toward each language - their heritage language, their first language, and other languages that they might be interested in. The fourth one provides 20 statements to explore the students' attitudes with a Likert scale for 4 choices: Strongly Agree, Agree, Disagree, and Strongly Disagree. The set of questions for the FGD consists of 18 questions to further explore, clarify, and confirm the students' responses to the questionnaire that reflect their attitudes.

The data were in the form of students' responses to the questionnaire, which served quantitative data, and the transcript of the recorded discussion. The students' responses to the first and second parts of the questionnaire were tallied and summarized in the form of tables, whereas the third and fourth parts were analysed quantitatively in percentages. The students' responses to the questions during the FGD serve as supporting data for clarification, confirmation, and further exploration. The data were analysed based on the aspects organised in the questionnaire and compared with the findings of Berman et al.'s (2011), Ehala and Niglas's (2006), and Nguyen's (2018)'s studies.

The data collection was conducted after we obtained the school principal's approval for the questionnaire distribution and the FGD. Prior to the questionnaire distribution and FGD, research consents from the school principal and each participant were collected. The printed questionnaires were distributed to the students to complete in approximately 20 to 30 minutes' time. After that, six of the 29 participants were sitting in a group-discussion forum held at the school library to help the students to speak conveniently as they were among their peers. The six students were chosen randomly due to the time constraint; two students from each of the three classes took part in the FGD. The data collected from the questionnaire were then tallied and presented in tables. The recording of the discussion was transcribed by a transcriber specifically hired for this purpose, and the transcription was then translated by the researchers to support the data analyses

\footnotetext{
*Author(s) Correspondence:

E-mail: kasih.er@atmajaya.ac.id; manara.christine@gmail.com
} 


\section{FINDINGS AND DISCUSSION}

Apparently, the language predominantly used by the students both academically and for social interaction purposes with their parents, siblings, peers, teachers, or other people is the language of the majority-Indonesian - in all the speech domains: classrooms, school, places outside school, dormitory, public religious places, and social media. Even though 17 of them admitted to use HL with their parents and 8 of them with their siblings, most of the time they used Indonesian.

RQ \#1: What are the students' attitudes towards languages and their heritage language?

While the majority of the students admitted being able to speak their HL, some admitted that they were not able to use their HL and they always used Indonesian, the national language and the lingua franca across the country. Statements 1, 8, 9, and 10 expressed their attitudes towards their HL(s).

Table 1. Students' attitudes towards their

HL

\begin{tabular}{|c|c|c|c|c|}
\hline \multirow[t]{2}{*}{ No } & \multirow[t]{2}{*}{ Statement } & \multicolumn{2}{|c|}{$\begin{array}{c}\text { Percentage } \\
(\%)\end{array}$} & \multirow{2}{*}{$\Sigma$} \\
\hline & & $\mathbf{A}$ & D & \\
\hline 1. & $\begin{array}{l}\text { I prefer } \\
\text { using HL } \\
\text { than } \\
\text { Indonesian } \\
\text { when } \\
\text { talking to } \\
\text { my parents. }\end{array}$ & 68.97 & 31.04 & 29 \\
\hline 8. & $\begin{array}{l}\text { I feel } \\
\text { reluctant } \\
\text { speaking in } \\
\text { HL with } \\
\text { friends at } \\
\text { school. }\end{array}$ & 37.93 & 62.07 & 29 \\
\hline 9. & $\begin{array}{l}\text { I am more } \\
\text { confident } \\
\text { when } \\
\text { speaking in } \\
\text { HL. }\end{array}$ & 37.93 & 62.07 & 29 \\
\hline
\end{tabular}

\begin{tabular}{|c|l|c|c|c|}
\hline 10. & $\begin{array}{l}\text { I am proud } \\
\text { of being } \\
\text { able to } \\
\text { speak HL. }\end{array}$ & $\mathbf{7 5 . 8 7}$ & 17.23 & 29 \\
\hline
\end{tabular}

The majority of these students come from districts where a variety of HLs are used within a community on the daily basis; some are able to understand and speak a variety of HLs with different speakers in their neighborhood. However, as they are from different districts with different varieties of HLs, it is difficult from them to speak HL with each other either at school or at the school dormitory. It seems they have no choice but to use Indonesian as the lingua franca. Besides, it is the language of instruction at school where they are studying now. Their attitudes towards Indonesian compared to HL are expressed in Table 2.

Table 2. Students' attitudes towards Indonesian compared to HL

\begin{tabular}{|c|l|c|c|c|}
\hline \multirow{2}{*}{ No. } & \multicolumn{1}{|c|}{ Statement } & \multicolumn{2}{|c|}{$\begin{array}{c}\text { Percentage } \\
\text { (\%) }\end{array}$} & \multirow{2}{*}{$\sum$} \\
\cline { 2 - 4 } & & A & D & \\
\hline 2. & $\begin{array}{l}\text { I prefer using } \\
\text { Indonesian to HL } \\
\text { when talking to } \\
\text { friends at the } \\
\text { dormitory. }\end{array}$ & $\mathbf{7 8 . 5 7}$ & 21.43 & 28 \\
\hline 3. & $\begin{array}{l}\text { I prefer using } \\
\text { Indonesian to HL } \\
\text { when talking to } \\
\text { friends at school. }\end{array}$ & $\mathbf{8 6 . 2 1}$ & 13.79 & 29 \\
\hline 4. & $\begin{array}{l}\text { I prefer using } \\
\text { Indonesian to HL } \\
\text { when talking to } \\
\text { teachers at } \\
\text { school. }\end{array}$ & $\mathbf{8 6 . 2 1}$ & 14.16 & 29 \\
\hline 5. & $\begin{array}{l}\text { I prefer using } \\
\text { Indonesian to HL } \\
\text { when discussing } \\
\text { lessons with } \\
\text { friends at school. }\end{array}$ & $\mathbf{9 3 . 1 1}$ & 6.9 & 29 \\
\hline 6. & $\begin{array}{l}\text { I prefer using } \\
\text { Indonesian to HL } \\
\text { when playing } \\
\text { (relaxing) with } \\
\text { friends at school. }\end{array}$ & $\mathbf{8 9 . 2 9}$ & 10.71 & 28 \\
\hline
\end{tabular}

*Author(s) Correspondence:

E-mail: kasih.er@atmajaya.ac.id; manara.christine@gmail.com 


\begin{tabular}{|c|l|l|l|l|}
\hline 7. & $\begin{array}{l}\text { I prefer using } \\
\text { Indonesian to HL } \\
\text { when playing } \\
\text { (relaxing)with } \\
\text { friends at the } \\
\text { dormitory. }\end{array}$ & $\mathbf{7 2 . 3 1}$ & 20.69 & 29 \\
\hline
\end{tabular}

In terms of language skills, their responses also show consistency-that they seem to be more comfortable using Indonesian, as shown in Table 3 below.

Table 3. Students' attitudes towards Indonesian and $\mathrm{HL}$ in terms of language skills

\begin{tabular}{|c|l|c|c|c|}
\hline \multirow{2}{*}{ No. } & \multicolumn{1}{|c|}{ Statement } & \multicolumn{2}{|c|}{$\begin{array}{c}\text { Percentage } \\
\text { (\%) }\end{array}$} & \multirow{2}{*}{ ₹ } \\
\cline { 2 - 4 } 11. & $\begin{array}{l}\text { Speaking } \\
\text { Indonesian and } \\
\text { HL are equally } \\
\text { easy. }\end{array}$ & 51.73 & 48.28 & 29 \\
\hline 12. & $\begin{array}{l}\text { Writing in } \\
\text { Indonesian and } \\
\text { in HL are } \\
\text { equally easy. }\end{array}$ & $\mathbf{7 5}$ & 25 & 28 \\
\hline 13. & $\begin{array}{l}\text { Reading in } \\
\text { Indonesian and } \\
\text { in HL are } \\
\text { equally easy. }\end{array}$ & $\mathbf{6 5 . 5 4}$ & 34.48 & 29 \\
\hline 14. & $\begin{array}{l}\text { Listening in } \\
\text { Indonesian and } \\
\text { in HL are } \\
\text { equally easy. }\end{array}$ & $\mathbf{5 5 . 1 7}$ & 44,83 & 29 \\
\hline 15. & $\begin{array}{l}\text { I think it is } \\
\text { easier to catch } \\
\text { the words in } \\
\text { conversations } \\
\text { in HL than } \\
\text { those in } \\
\text { Indonesian. }\end{array}$ & 42.36 & $\mathbf{5 8 . 6 3}$ & 29 \\
\hline
\end{tabular}

Students attitudes towards language uses in the future are reflected in Table 4 below. More than half of all the students agreed that Indonesian is more useful than HL in their future study and career. However, more than $30 \%$ of them disagreed. These students may refer to foreign languages such as English and other foreign languages they are interested in, as more than $96 \%$ agreed on the importance of learning other languages.

Table 4. Students attitudes towards languages for future use

\begin{tabular}{|c|c|c|c|c|}
\hline \multirow[t]{2}{*}{ No. } & \multirow[t]{2}{*}{ Statement } & \multicolumn{2}{|c|}{$\begin{array}{c}\text { Percentage } \\
(\%)\end{array}$} & \multirow[t]{2}{*}{$\Sigma$} \\
\hline & & $\mathbf{A}$ & D & \\
\hline 16. & $\begin{array}{l}\text { I think } \\
\text { Indonesian is } \\
\text { more useful } \\
\text { than HL in my } \\
\text { future study. }\end{array}$ & 65.51 & 35.47 & 29 \\
\hline 17. & $\begin{array}{l}\text { I think } \\
\text { Indonesian is } \\
\text { more useful } \\
\text { than HL in my } \\
\text { future career. }\end{array}$ & 63.05 & 37.93 & 29 \\
\hline 20. & $\begin{array}{l}\text { Besides } \\
\text { Indonesian, } \\
\text { learning other } \\
\text { languages is } \\
\text { important. }\end{array}$ & 96.55 & 3.45 & 29 \\
\hline
\end{tabular}

The students' positive attitudes towards the maintenance of HL are shown in Table 5. Such positive attitudes seem to reflect their feeling of connectedness with their families even though their responses when asked about the frequency of their using HL showed that most seldom use it, and some even never use it. The only opportunity they find to use their HL is when they are communicating with their families on the phone. Even though they live with their peers who come speak the same HL in the same dormitory, they prefer using Indonesian on a daily basis.

Table 5. Students' attitudes towards the maintenance of $\mathrm{HL}$

\begin{tabular}{|c|l|c|c|c|}
\hline \multirow{2}{*}{ No. } & \multirow{2}{*}{ Statement } & \multicolumn{2}{|c|}{$\begin{array}{c}\text { Percentage } \\
\text { (\%) }\end{array}$} & \multirow{2}{*}{$\Sigma$} \\
\cline { 3 - 4 } 18. & $\begin{array}{l}\text { HL should } \\
\text { continuously be } \\
\text { used. }\end{array}$ & $\mathbf{9 6 . 5 5}$ & 3.45 & 29 \\
\hline 19. & $\begin{array}{l}\text { By continuously } \\
\text { using my HL, I } \\
\text { take part in } \\
\text { preserving HL. }\end{array}$ & $\mathbf{9 6 . 5 5}$ & 3.45 & 29 \\
\hline
\end{tabular}

*Author(s) Correspondence:

E-mail: kasih.er@atmajaya.ac.id; manara.christine@gmail.com 
RQ \#2: What other languages are they investing in?

The language most students are interested in learning is apparently English. However, they also show interest in learning other foreign languages such as German, Latin, Spanish, Russian, French, Mandarin, Korean, Portuguese, Japanese, and Puerto Rico. Interestingly, some of them admitted being interested in learning their HL such as Asmat, Karon, and Biak; and also other local languages: Sundanese, Bataknese, and Javanese. The heritage language studied at school refers to Sundanese, the language of the local communities living surrounding the school areas and dormitory.

Table 6. Students' language investment

\begin{tabular}{|l|c|c|c|c|}
\hline \multirow{2}{*}{ Questions } & \multicolumn{4}{|c|}{ Number of students } \\
\cline { 2 - 5 } & INA & HER & ENG & Others \\
\hline $\begin{array}{l}\text { Languages } \\
\text { studied at } \\
\text { school }\end{array}$ & 17 & 23 & 23 & 15 \\
\hline $\begin{array}{l}\text { Languages } \\
\text { I am } \\
\text { interested } \\
\text { in learning }\end{array}$ & 8 & 12 & 23 & 10 \\
\hline
\end{tabular}

Notes: INA: Indonesian; HER: Heritage;

ENG: English

\section{$R Q$ \#3: Why are they investing in that (those) language(s)?}

The reasons for them to learn these other languages can be seen in the Table 7 .

Table 7. Students' reasons for language investment

\begin{tabular}{|c|l|c|}
\hline No. & \multicolumn{1}{|c|}{ Reason } & \% \\
\hline 1. & $\begin{array}{l}\text { To visit places where } \\
\text { the language is } \\
\text { widely used. }\end{array}$ & 37.93 \\
\hline 2. & $\begin{array}{l}\text { To visit the country } \\
\text { that the language is } \\
\text { originated from. }\end{array}$ & 34.48 \\
\hline 3. & $\begin{array}{l}\text { To continue my study } \\
\text { in that country where } \\
\text { the language is } \\
\text { originated from. }\end{array}$ & 51.72 \\
\hline
\end{tabular}

\begin{tabular}{|l|l|l|}
\hline 4. & $\begin{array}{l}\text { To prepare for my } \\
\text { future career. }\end{array}$ & 48.28 \\
\hline
\end{tabular}

They also mentioned some other reasons, such as to be able to speak with the speakers of the languages they are investing in, to get knowledge of the wide world and many other things such as (diverse) traditions; and one student shows interest in marrying someone who comes from the country of the language origin. Meanwhile, their reason to study the local language is to understand the local culture.

\section{$R Q$ \#4: What are the values of each language to them?}

Even though the participants still perceive their HL important, they see it as a means to connect themselves with their culture - a "token of identity and not so much as a commodity in the sense of linguistic economy" (Ehala and Niglas, 2006, p. 209). Therefore, they do not show the urgency of using it more frequently on the daily bases in spite of their awareness of its importance. Their attitudes about their HL "seem incompatible with their language behaviour" (Baker, 1992, as cited in King, 2000, p. 167). A growing interest in learning other languages - the influence of the internet for economic and social reasons: future studies/career and admiration of the sophisticated facilities offered in overseas schools/universities. As the internet has been present in their daily life, these students have been exposed to the world, and get new knowledge of different cultures and languages brought by the internet. Unlike most of the respondents in Velázquez's (2017) study, who still use their HL-Spanish-for communicating in social media, texting, and media consumption, the respondents in this study acknowledge to prefer Indonesian and even English for similar reasons.

\section{Discussion}

Great difficulty in using $\mathrm{HL}$ - the presence of a wide range of variety of HLs, even in the same tribe-seems to have

*Author(s) Correspondence:

E-mail: kasih.er@atmajaya.ac.id; manara.christine@gmail.com 
impeded the students from using it conveniently with their family or peers, and as a result, they turn to Indonesian, the lingua franca. Even though they seem to see the importance of maintaining their HL, they slowly stop using it and turn to other languages for several reasons: integrating to the society (the majority) and preparing themselves for the future study or career. Leaving their home island to seek better opportunities for free education seems to have contributed in a faster language shift from HL to the dominant language of the majority and even to foreign languages. It is perceived faster, as the language shift seems to have started even before they left their homeswhen they had to use the lingua franca to communicate to the people they met in their lives - those who come from diverse ethnic groups. Although some admitted having been able to use HL when meeting families/relatives, they have started to mix HL and Indonesian.

S6: Kalau saya pakai bahasa daerah dan bahasa Indonesia juga.

(S6: In my case, I speak my ethnic language and Indonesian as well.

$\mathrm{R}:$ Bahasa daerahnya apa?

(R: What's the name of the ethnic language?)

S6: Bahasa Walat.

(S6: The Walat language.)

R: Di daerah mana?

(R: In which district (do you speak the language?)

S6: Di Wamena.

(S6: In Wamena.)

...

R: Dengan ayah-ibu? Sama bahasanya?

(R: How about with your father or mother?)

S6: Lya, sama.

(S6: Yes, the same (language)).

R: Bahasa Walat ini?

(R: This Walat language?)

S6: Iya.

(S6: Yes.)

$\mathrm{R}:$ Lalu dengan tetangga?

( How about with your neighbors?)

S6: Tetangga? Beda juga.

(S6: (Communicating with) neighbors? Different (languages).)

R: Boleh tahu apa nama bahasanya?
(R: Can you tell me the name of the language (you use with your neighbor)?)

S6: Bahasa Lani.

(S6: The Lani language.)

The shift seems to have an effect on their language proficiency of HL. Polinsky $(2015$, p.7) decribes heritage speakers to have a cultural or familial connection to their heritage language, but they are linguistically better in performing themselves in using the dominant language. A similar case seems to occur among the adolescents in this study. They hardly practice using their HL with their peers who come from the same ethnic at school or school dormitory or with their families on the phone; they tend to prefer using the dominant language-Indonesian - to using their HL. They perceive HL as a cultural or familial connection in a similar way as the adolescents in Alsahafi's (2019) and Huia's (2015) studies value their HL learning.

While there is a language shift from Estonian to English in Ehala and Niglas's (2006) study, from Vietnamese to English in Nguyen's (2018), from Korean to English in Cho's (2015), and from Polish to Icelandic in Berman et al.'s (2011), this study shows a language shift among the majority of the students from HL to Indonesian. A similar language shift can also be seen in Little's (2020) and Farr et al.'s (2018) studies, in which the children in their studies show a tendency to use the language used in the community for social interaction more frequently than their HL. The language shift may occur because the Papuan adolescents in this study rarely find opportunities to practice using their HL with their families; even when they communicate by phonecalls or WhatsApp they tend to use Indonesian- a similar situation in which parents no longer speak the HL or they find difficulty because of their weak competencies in using HL (Budiyana, 2017).

Based on the students' responses during the FGD, all the students seemed to try to invest in English and other foreign languages, such as Japanese, Korean, Latin, German, Hebrew, and Greek for future studies

\footnotetext{
*Author(s) Correspondence:

E-mail: kasih.er@atmajaya.ac.id; manara.christine@gmail.com
} 
or visits. They apparently recognize the status of English as an international language and realize that having good English proficiency is a must if they want to study overseas in their future. One of the students wanted to invest in Hebrew and Greek for a religious purpose- to prepare himself to be a religious leader; another wanted to invest in German and Latin to prepare himself for a medical school, as shown in the following dialogue:

R: Sangat tertarik? Atau ada bahasa lain lagi yang ingin dipelajari selain bahasa Inggris?

(R: Very interested? Or are there any other languages you want to learn beside English?)

S1: Bahasa Jerman dan Latin.

(S1: German and Latin)

R: Kenapa Jerman dan Latin?

(R: Why German and Latin?)

S1: Jerman, karena mau ngambil kuliah $S 2$ di sana. Kedokteran.

(S1: German, because (I) want to take a master degree there. Majoring in Medical.)

Another seemed to be a K-Pop fan and therefore wanted to visit (South) Korea; and the other pursued an opportunity to visit Japan to practice speaking the language.

In this case, according to Norton (2000 as cited in Norton \& Toohey, 2011, p. 420) these students invest in the language because it can help them "acquire a wider range of symbolic and material resources, which will, in turn, increase the value of their cultural capital", which will affect their future. They admitted they made efforts for learning English by listening to English songs, watching movies, taking notes of vocabulary by using dictionaries, reading English books.

R: Selain mendengarkan lagu ada lagi yang lain? (R: Beside listening to songs, is there anything else?)

S4: Menulis vocab.

(S4: Writing vocabulary--words)

S1: Nonton film.

(S1: Watching movies)

$\mathrm{R}$ : Belajar vocab, gimana? (directing the question to $S 4)$

(R: Learning vocabulary: how do you do that?)

S4: Ya itu, cari kata-kata gitu di kamus.

(S4: Well, looking up words in the dictionary)
$\mathrm{R}$ : Kalau (directing the question to $\mathrm{S} 2$ )

(R: How about you?)

S2: Saya lebih banyak speak...

(S2: I practice more speaking...)

They also admitted to communicate in English face-to-face with their peers or in social media - common strategies among adolescents as those strategies were also practiced by the adolescents learning Icelandic (Berman et al., 2011), and those learning their Korean as their HL (Cho, 2015). Two of them also mentioned communicating in English with their older sibling studying overseas by Skype or videocall; and one admitted to get to know Latin from the internet, and decided to invest in it. These reflect the $21^{\text {st }}$ century generation in being the citizen of the global world. They communicate meanings "not only through text but also through music, sound, images, and a variety of digital media," a new redefinition of being literate in the $21^{\text {st }}$ century (Coiro et al. 2000 , p. 10 as cited in Norton \& Toohey, 2011, p. 432-433).

Interestingly, they also admitted to be interested in Sundanese - one of their school subject and the language of the local living surrounding the school and the dormitory.

S1 \& S2: Di kelas biasanya bicara bahasa Sunda.

(S1 \& S2: In the class (we) usually speak Sundanese.)

R: Oh, di kelas?

(R: Oh, in the class?)

S1: Bahasa lokalnya kan bahasa Sunda.

(S1: The local language here is Sundanese.)

R: Oh, belajar....mempelajari bahasa Sunda.

Kalau menggunakan?

(R: Oh, (you) learn Sundanese. How about using it?)

S1: Bisa juga dikit-dikit.

(S1: (we) can (use rhe language), a little.)

Willingness to learn the local language (Sundanese) for survivor reasoncommunicating on the daily basis, e.g. with the 'angkot' (public transportations) drivers, or 'warung' (a food stall) owners. Referring to Nguyen (2018), that is a clear sign of their choosing to be part of the mainstream. They have even started using the language on the

\footnotetext{
*Author(s) Correspondence:

E-mail: kasih.er@atmajaya.ac.id; manara.christine@gmail.com
} 
daily basis, which means they seem to want to integrate to the society system, as shown by the subjects in Berman et al.'s (2011) study. Similarly, the Korean adolescents in Cho's (2015) study apparently switch to English to integrate to the social lives of the majority in the U.S.

\section{CONCLUSION AND SUGGESTIONS}

\section{Conclusion}

Moving across space and time zones to a far-away land that is different in terms of language and culture seems to have driven the adolescents in this study to experience a language shift from HL to Indonesian, the dominant language. The new environment that has introduced them to more technology also seems to have brought them the desire to prepare for better future by investing in other languages - other than Indonesian and HL. Even though there is a glimpse of hope that they are still willing to maintain their HL, as it connects them to their culture, and a hope they might pass their HL to their children in the future - as some admitted to want to learn their HL, there is a fear that the language shift they are experiencing and the language investment that they are practicing may pull them away from HL preservation. Of course it is time that will answer this fear that their will no longer hold to their "past experience which a group deliberately sets out to preserve and pass on to the next generation (Rampton 2006, p. 20, as cited in Blackledge \& Creese, 2008, p. 536).

\section{Suggestions}

The result of this study does not represent all the adolescents coming from the same districts, and does not intend to generalize the students' attitudes toward languages and maintenance of HL. There can be many aspects that affect the results of this study, which makes it applicable only to this group of students. This means, rooms for further exploration on language heritage among adolescents are widely open. The dynamic global changes due to the COVID 19 pandemic make the exploration worth trying, as they may offer new perspectives towards maintenance of heritage language and language shift.

\section{ACKNOWLEDGEMENTS}

We thank the foundation, the school principal, and teachers for their consent and support, and specially thank all the students who willingly took part in this research.

\section{REFERENCES}

Alsahafi, M. (2019). Language maintenance and heritage language education: The case of a weekend Arabic school in New Zealand. IJALEL 8(2), 21-29. http://dx.doi.org/10.7575/aiac.ijalel.v. 8n.2p.21

Armon-Lotem, S., Rose, K., \& Altman, C. (2021). The development of English as a heritage language: The role of chronological age and age of onset of bilingualism. First Language 4(1), 6789. DOI: $10.1177 / 0142723720929810$

Altarriba, J. \& Heredia, R. R. (2008). An introduction to Bilingualism: Principles and processes. New York: Taylor \& Francis Group.

Berman, R., Lefever, S., \& Woźniczka, A. K. (2011). Attitudes towards languages and cultures of young Polish adolescents in Iceland. Ráðstefnurit Netlu-Menntakvika, 1-16.

Blackledge, A. \& Creese, A. (2008). Contesting 'language' as 'heritage': Negotiation of identities in late modernity. Applied Linguistics, 29(4), 533-554.

Budiyana, Y. E. (2017). Students' parents' attitudes toward Chinese heritage language maintenance. Theory and Practice in Language Studies, 7(3), 195-200. DOI: http://dx.doi.org/10.17507/tpls.0703.0 $\underline{5}$

Cho, G. (2000). The role of heritage language in social interactions and

\footnotetext{
*Author(s) Correspondence:

E-mail: kasih.er@atmajaya.ac.id; manara.christine@gmail.com
} 
relationships: Reflections from a language minority group. Bilingual Research Journal, 24(4), 369-384.

Cho, G. (2015). Perspectives vs. reality of heritage language development: Voices from second-generation Korean-American high school students. Multilingual Education. 3038.

Darvin, R. \& Norton, B. (2016). Investment and language learning in the $21^{\text {st }}$ century. Langage et société 3 (157), 19-38.

Ding, S. L. \& Goh, K. L. (2019). The impact of religion on language maintenance and shift. Language in Society 49, 3159. doi:10.1017/S0047404519000642

Ehala, M. and Niglas, K. (2006). Language Attitudes of Estonian Secondary School Students. Journal of Language, Identity, and Education, 5(3), 209227.

Farr, J., Blenkiron, L., Harris, R., \& Smith, J.A. (2018). "It's my language, my culture, and it's personal!" Migrant mothers' experience of language use and identity change in their relationship with their children: An interpretative phenomenological analysis. Journal of Family Issues, 39(11), 3029-3054. DOI: $10.1177 / 0192513 \times 18764542$

Huia, A. T. (2015). Exploring goals and motivations of Māori heritage language. SSLLT 5 (4), 609-635. doi: 10.14746/ssllt.2015.5.4.5

King, K. A. (2000). Language ideologies and heritage language education. International Journal of Bilingual Education and Bilingualism, Vol. 3/3. 167-184.

Little, S. (2020). Whose heritage? What inheritance?: conceptualising family language identities. International Journal of Bilingual Education and Bilingualism, 23(2), 198-212 https://doi.org/10.1080/13670050.201 7.1348463
Nguyen, T.T. (2018). Bilingual identity of ethnic minority students: insights from Vietnam. International Journal of Bilingual Education and Bilingualism. 1-16.

Norton, B. \& Toohey, K. (2011). Identity, language learning, and social change. Language Teaching, 44/4. 412-446.

Polinsky, M. (2015). Heritage languages and their speakers: State of the field, challenges, perspectives for future work, and methodologies. Zeitschrift für Fremdsprachenforschung, 26: 1, S. 7-27.

Russell, B. D. \& Kuriscak, L. M. (2015). High school Spanish teachers' attitudes and practices toward Spanish heritage language learners. Foreign Language Annals, 48(3), 413-433. DOI: 10.1111/flan. 12145

Velázquez, I. (2017). Reported literacy, media consumption and social media use as measures of relevance of Spanish as a heritage language. International Journal of Bilingualism 21(1), 21-33. DOI: $10.1177 / 1367006915596377$

*Author(s) Correspondence:

E-mail: kasih.er@atmajaya.ac.id; manara.christine@gmail.com 